\title{
Sequential resuspension of biofilm components (viruses, prokaryotes and protists) as measured by erodimetry experiments in the Brouage mudflat (French Atlantic coast)
}

\author{
Christine Dupuy $^{\mathrm{a}, *}$, Clarisse Mallet ${ }^{\mathrm{b}}$, Katell Guizien ${ }^{\mathrm{c}}$, Hélène Montanié ${ }^{\mathrm{a}}$, Martine Bréret $^{\mathrm{a}}$, \\ Françoise Mornet $^{d}$, Camille Fontaine ${ }^{a}$, Caroline Nérot ${ }^{a, e}$, Francis Orvain ${ }^{\dagger}$
}

\footnotetext{
a Littoral, Environnement et SociétéS (LIENSs), Université de La Rochelle, UMR 7266 CNRS-ULR, 2 rue Olympe de Gouges, 17000 La Rochelle Cedex, France

${ }^{\mathrm{b}}$ Laboratoire Microorganismes, Génome et Environnement, UMR 6023 CNRS-Université de Clermont-Ferrand II, 24 avenue des Landais, 63177 Aubière Cedex, France

c Laboratoire d'Ecogéochimie des Environnements Benthiques, UMR 8222, CNRS/UPMC, Observatoire Océanologique de Banyuls-sur-Mer, 66650 Banyuls-sur-Mer, France

${ }^{d}$ Laboratoire Ressources Halieutiques de La Rochelle, Ifremer, Station de La Rochelle, Place Gaby Coll - BP 7 17137 L'Houmeau, France

e LEMAR - UMR 6539 - Institut Universitaire Européen de la Mer Place Nicolas Copernic 29280 Plouzané, France

${ }^{\dagger}$ Université de Caen Basse-Normandie, FRE3484 BioMEA CNRS, Esplanade de la Paix, F-14032 Caen, France

*: Corresponding author : Christine Dupuy, tel.: + 33546457218 ; email address : cdupuy@univ-Ir.fr
}

\begin{abstract}
:
Resuspension thresholds in terms of friction velocity were experimentally quantified for the prokaryotes, protists and for the first time, viruses of intertidal mudflat biofilms. Differences in resuspension thresholds could be related to the type, behaviour and size of microorganisms and their association with particles. Free microorganisms (viruses, bacteria and some nanoflagellates) were resuspended by weak flow at friction velocities lower than $2 \mathrm{~cm} \mathrm{~s}^{-1}$. Chlorophyll a, some nanoflagellates and attached bacteria were resuspended together with the bed's muddy sediment, which required friction velocities larger than $3 \mathrm{~cm} \mathrm{~s}^{-1}$. Diatoms smaller than $60 \mu \mathrm{m}$ were resuspended at velocities between 3 and $5 \mathrm{~cm} \mathrm{~s}^{-1}$, while those larger than $60 \mu \mathrm{m}$ were resuspended at higher friction velocities (5.5 to $6.5 \mathrm{~cm} \mathrm{~s}^{-1}$ ).
\end{abstract}

The thresholds of resuspension also depended on the micro-scale position of microorganisms in the sediment (horizontal and vertical distribution). In the field, the vertical distribution of chlorophyll a (a proxy of microphytobenthos) was skewed, with a maximum in the first $2 \mathrm{~mm}$ of sediment. Along the neap-spring tidal cycle, chlorophyll a revealed an increase in MPB biomass in the first $2 \mathrm{~mm}$ of the sediment, in relation to light increases with exposure durations. The horizontal distribution of chlorophyll a could be inferred from erosion experiments. During the initial phase of biofilm growth, the distribution of chlorophyll a seemed horizontally homogeneous, and was uniformly eroded at the beginning of the increase in chlorophyll a. From these results, we can make a hypothesis: in the subsequent phase of biofilm growth until the maximum of emersion duration, the eroded quantity of chlorophyll a was larger than expected based from chlorophyll a vertical distribution, suggesting that biofilm horizontal distribution became patchy and enriched chlorophyll a were preferentially eroded. When emersion duration and biofilm growth decreased, the trend was reversed, and eroded quantity of chlorophyll a was lower than expected from chlorophyll a vertical distribution, suggesting that areas 
with low chlorophyll a were preferentially eroded. Such erosion patterns when biofilm growth decreased probably resulted from the bulldozing activity of a surficial sediment bioturbator, the gastropod Peringia ulvae. Our study did not directly prove this horizontal distribution but it should be further discussed. This distribution need to be studied to acquire real evidence of patchy distributions.

\section{Highlights}

Biofilm resuspension thresholds could be related to the type, behaviour and size of microorganisms, and their association with particles. Free microorganisms (e.g. viruses) were resuspended by weak flow with friction velocity lower than $2 \mathrm{~cm} \mathrm{~s}^{-1}$. Microphytobenthos, some nanoflagellates and attached bacteria were resuspended with friction velocity larger than $3 \mathrm{~cm} \mathrm{~s}^{-1}$. Temporal variability in biofilm erosion patterns suggest the role of horizontal and vertical micro-scale biofilm heterogeneity in determining resuspension dynamics.

Keywords : Viruses ; Microorganisms ; Resuspension ; Benthic-pelagic coupling ; Spatial distribution; Mudflat

\section{Introduction}

The productivity of coastal systems, especially intertidal mudflats, and their capacity to enrich the adjacent terrestrial and marine zones through trophic (export by mobile consumers) and hydrodynamic pathways (waves, wave-generated and estuarine currents and tides) is now well known. Biological productivity in European intertidal mudflats predominantly relates to the presence of microphytobenthos (MPB) (MacIntyre et al., 1996 and Underwood and Kromkamp, 1999). MPB, mainly benthic diatoms, form biofilms during the emersion phase, up to $20 \mathrm{mg}$ chlorophyll $\mathrm{a} \mathrm{m}^{-2}$ at the very surface of the mud in Marennes-Oléron bay in France ( Blanchard and Cariou-Le Gall, 1994, Blanchard et al., 1997 and Herlory et al., 2004). The term "biofilm" refers to a complex assemblage of both eukaryotic and prokaryotic cells living on and in the sediment. In European intertidal mudflats, assemblages are dominated by epipelic diatoms, a heterogeneous group of eukaryotic phototrophs which can represent up to $97 \%$ of the whole microphytobenthic community ( De Jonge and Colijn, 1994 and Méléder et al., 2005). Prokaryotes, especially bacteria, are very abundant, with generally $10^{9}$ cells $\mathrm{cm}^{-3}$ of sediment (Pascal et al., 2009). Nanoflagellate abundance ranges from $10^{2}$ to some millions of cells $\mathrm{cm}^{-3}$ of fresh sediment (Gasol, 1993), while ciliates are more abundant in fine sand $\left(10^{2}\right.$ to $10^{3}$ ciliates $\mathrm{cm}^{-3}$; Epstein, 1995 and Fenchel, 1969) than in muddy sediment enriched with organic matter (Giere, 1993). Viruses are also abundant in marine sediments, about $10^{6}-10^{10}$ viruses $\mathrm{mL}^{-1}$ of fresh sediment (Breitbart et al., 2004). Cyanobacteria, euglenoids and dinoflagellates are generally present in smaller amounts ( 1 to 2 cells $\mathrm{cm}^{-3}$; Honeywill et al. 
2002; MacIntyre et al., 1996; Paterson, 1986). These cells, forming a transient biofilm, sustain the benthic food web but also play a key role in sediment biostabilisation (Decho, 2000; Miller et al., 1996; Underwood et al., 1995).

The main factor influencing the vertical distribution of MPB in the sediment is their migration, which is directly induced by light and tides (Mitbavkar and Anil, 2004) with possible relationships with nutrient requirements, for these autotrophic organisms. Vertical migration causes short-term variability of MPB biomass within 2 and $5 \mathrm{~mm}$ of the sediment surface (Sauer et al., 2002). An evident migratory rhythm exists, with migration up to the surface during daytime emersion and down into deeper sediment during night and submersion (Serôdio et al., 1997). Migrating cells may reach sediments as deep as 6 or even $10 \mathrm{~mm}$ (Mitbavkar and Anil, 2004). At the beginning of the low tide, MPB colonises the sediment surface rapidly (within $15 \mathrm{~min}$ ); $75 \%$ of the biomass contained in the top $1 \mathrm{~mm}$ was concentrated in the upper $200 \mu \mathrm{m}$, but the cover never reached 100\% (Herlory et al. 2004). At the end of the emersion phase ( $4 \mathrm{~h} 15$ of emersion phase), the horizontal distribution of the microphytobenthic biofilm was scattered on the surface of the sediment due to the onset of downward migration. The downward return in depth was slow, showing that the diatoms were not phased in their downward movement. The migration process thus appeared to be asymmetrical in terms of rapid upward migration and biofilm formation versus slow downward movement and dispersion of the biofilm, in the depth of sediment or resuspended (Herlory et al., 2004; Mitbavkar and Anil, 2004). Irradiance has a stronger effect than tides in controlling/regulating microscale migrations in benthic diatoms (Mitbavkar and Anil, 2004). Other factors could also play a role in the vertical distribution of microorganisms, e.g.: oxygen, nutrient, and organic matter concentration; resuspension; and mixing and burial processes determined by hydrodynamic forcing and bed-form morphology (Brotas et al., 1995; de Brouwer et al., 2000; Lucas et al., 2000).

Sediment resuspension plays an integral role in coupling the benthos and plankton by transferring nutrients, detritus, and microorganisms to the water column (Garstecki et al., 2002; Wu et al., 2007). Resuspension of microorganisms living either in the surficial sediment pore water or attached to surficial sedimentary particles has been recorded under the action of tidal currents at subtidal sites (Shimeta et al., 2002) and intertidal sites (Christiansen et al., 2006; Orvain et al., 2007; Guizien et al., 2013; Mallet et al., this issue; Orvain et al., this issue). An important question regarding the resuspension process is whether microorganisms are resuspended as a group, characterised by a single threshold level of bed shear stress or whether they are sequentially resuspended with different threshold levels of bed shear stress. 
It is expected that resuspension varies with cell size, shape or density of the microorganisms, vertical distribution, migratory behaviour or associations with particles. Protists and bacteria resuspension friction velocity thresholds were estimated to range from 0.25 to $0.80 \mathrm{~cm} \mathrm{~s}^{-1}$ at a subtidal coastal site (unconsolidated sediment) with in situ flumes, by sampling the benthic boundary layer during tidal accelerations (Shimeta et Sisson, 1999; Shimeta et al., 2002; 2003). But, resuspension of viruses, protistan communities, microalgae, and prokaryotes are largely unknown in intertidal sites, where sediment erodibility can vary drastically across the intertidal area (Guizien et al., 2012). Low erodibility values can be found after dessication in consolidated sediment while high erodibility values will be found in bioturbated areas related to the creation of a biogenic matrix (slime exudates) caused by particle reworking, as well as to sedimentary-matrix loosening by macrofauna (Orvain et al. 2004; Montserrat et al. 2008; Van Colen et al. 2008). Blanchard et al. (1997) found that MPB eroded before bacteria in flume experiments with intertidal mud, apparently because of the association of the diatoms with the easily eroded and mucus-rich biogenic matrix (slime exudates) from mud snails. Generally speaking, bioturbation activities can bulldoze the surface so drastically that the vertical and horizontal distribution of MPB is disturbed, along with their resuspension flux.

To date, only a few studies have focused qualitatively and quantitatively on the resuspension of microorganisms present in intertidal mudflats. Protists and bacteria resuspension thresholds were studied at a subtidal coastal site with in situ flumes by sampling the benthic boundary layer during tidal accelerations (Shimeta et Sisson, 1999; Shimeta et al., 2002) and during an in situ rising-tide survey from low tide to high tide (lagrangian survey) (Guizien et al., 2013). Shimeta et al. (2003) studied the resuspension of benthic protists at subtidal coastal sites with differing sediment composition. Other studies focused on the effects of experimental subtidal sediment resuspension on a coastal planktonic microbial food web (Garstecki et al., 2002; Wu et al., 2007). But resuspension on viruses, protistan communities, microalgae, and prokaryotes are largely unknown in intertidal sites. Some bibliographic references focused only on the effective resuspension of microphytobenthic chlorophyll $a(\mathrm{chl} a)$ and suspended total particulate matter (TPM) from the intertidal flat into the water column in Europe (Paterson 1989; Blanchard et al., 1997; Austen et al., 1999; Herman et al., 2001; Lucas et al., 2001; Orvain et al., 2004, 2007; de Brouwer et al., 2005; Andersen et al., 2010) and in Japan (Koh et al., 2006). In addition, these papers demonstrated that benthic microalgae stabilise the sediment surface (Paterson 1989; de Brouwer et al. 2005; Andersen et al. 2010; De Backer et al. 2010; Van Colen et al. 2012), whereas the benthic 
macrofauna has a destabilising effect by the process of bioturbation (Austen et al., 1999; Herman et al., 2001; Orvain et al., 2004, 2007).

In this study, we analysed and quantified the sequential resuspension of microorganisms (viruses, protists and prokaryotes) along a neap-spring tidal cycle in July 2008 in the Brouage (France) intertidal mudflat. This study reports the first data concerning the resuspension of viruses at an intertidal mudflat. All experiments were performed with a mobile erosion device (see details in Orvain et al., this issue). We quantified both physical conditions for resuspension of sediment (bed friction velocity, $\mathrm{u}^{*}$; critical bed friction velocity, $\mathrm{u}^{*}$ crit) and sequential resuspension of microorganisms (viruses, prokaryotes, nanoflagellates, ciliates and diatoms). Sequential resuspension observations are discussed by considering the possible explanation of a spatial distribution of MPB.

\section{Material and methods}

Study site

The study was carried out in the Marennes-Oleron Bay (BMO, French Atlantic coast), a macrotidal bay located on the French Atlantic coast, between the mainland Atlantic coast of France and Oléron Island. This macrotidal system is influenced by a tidal range of $6 \mathrm{~m}$ during spring tides and continental inputs mainly from the Charente River and occasionally from the Gironde River (Bassoulet et al., 2000). The bay covers $170 \mathrm{~km}^{2}$, of which $60 \mathrm{~km}^{2}$ are intertidal mudflats. The Brouage mudflat is $>4 \mathrm{~km}$ wide and the sediment mainly consists of silt and an average of clay particles (95\% of volume of particles $<63 \mu \mathrm{m}$ in diameter, unimodal grain-size distribution with median value of $11 \mu \mathrm{m})$. Two sediment cores $(9 \mathrm{~cm}$ in diameter) were taken, for erodimetry experiments, at low tide (middle of the emersion period) in the central part of the mudflat $\left(45^{\circ} 54^{\prime} 50^{\prime \prime} \mathrm{N}, 01^{\circ} 05^{\prime} 25^{\prime \prime} \mathrm{W}\right)$ using a hovercraft in July 2008 before $(17,18,19)$, during $(21)$ and after $(22,23,24,25)$ spring tides. Only ridges were sampled, since biofilms are normally not found in runnels (Blanchard et al., 2000). On each date, 3 additional cores $(15 \mathrm{~cm}$ in diameter) were taken in order to assess Peringia ulvae (gastropods) densities (individuals $\mathrm{m}^{-2}$ ).

\section{Erodimetry experiments}

We quantified bed erodibility and sequential resuspension of microorganisms during erosion experiments performed with an erosion device in the "Erodimetre", a straight tunnel 
with recirculating flow discharge regulated by a pump, all called an "erodimetre" (Le Hir et al., 2006; Orvain et al., 2007; Orvain et al., this issue). Two sediment cores (9 $\mathrm{cm}$ of diameter) were sampled in the field, were quickly taken to the laboratory and were placed in the erodimetre to simulate erosion at the time of tidal flow in the field site. Filtered (Whatmann GF/F filter) artificial seawater (Sigma) was used to fill up the flume to obtain seawater that was very clean and without microorganisms. Flow discharge was increased by a step of $0.0633{\mathrm{~L} . \mathrm{s}^{-1}}^{-1}$ from 0.12 to $2.02 \mathrm{~L} . \mathrm{s}^{-1}$ with a succession of 32 steps. Each experiment consisted of two phases: 1) during a first phase when sediment erosion was low, flow discharge was increased every 2 min; and 2), during a second phase, the flow discharge was increased every $5 \mathrm{~min}$. The steps were lengthened as soon as the erosion was visually observed at the surface of sediment. Longer steps were applied at higher flow speed to ensure that the total quantity of erodible sediment at each discharge step was eroded. Friction velocity was calculated as the square root of bed shear stress divided by sea water density. Bed shear stress depends not only on flow velocity, but also on the bottom roughness. We used for these experiments the investigation by Guizien et al (2012) to take into account bottom roughness differences in the calculation of the Bed Shear Stress (BSS) on the basis of Shield criterion and hydraulic calibration over plates with different controlled roughness. Head loss between tunnel cross sections located upstream and downstream of the test section was used to directly determine the average bed shear stress over the core samples. Subtracting equations of steady-state momentum balance between upstream and downstream of the test section with plexiglass caps and samples with any roughness, the average bed shear stress on rough samples:

$$
\sigma_{\text {rough }}=\sigma_{\text {smooth }}+\frac{S 1}{2 S 3}\left(\Delta H_{\text {caps }}-\Delta H_{\text {cors }}\right)
$$

where $\tau_{\text {smooth }}$ and $\Delta \mathrm{h}_{\text {caps }}=$ are average bed shear stress and head loss, respectively, over hydraulically smooth plexiglass caps replacing cores in the test section; S1 = tunnel crosssection area; $\mathrm{S} 3=$ core area; and $\Delta \mathrm{h}_{\text {core }}=$ head loss with rough cores. The second term in Eq. (1) is the excess bed shear stress as a result of the core roughness compared to hydraulically smooth plexiglass caps.

Once the sediment and water were settled in the flume (in 1 hour), the flow was accelerated step by step until maximum friction velocity $\left(11 \mathrm{~cm} \mathrm{~s}^{-1}\right)$. Flow discharge, pressure head loss, and turbidity were continuously recorded during erosion experiments. The erosion of fine particles was estimated by a turbidity sensor that was calibrated with water samples taken during each erosion experiment. To do so, a duplicated volume of $1.5 \mathrm{~L}$ was sampled and filtered (on Whatmann GF/F filter) at 6 different flow levels (steps 2, 8, 12, 16, 20 and 
$25)$ for measuring the total mass of dry sediment $\left(\mathrm{g} \mathrm{L}^{-1}\right)$ and chl a concentration $\left(\mu \mathrm{g} \mathrm{L}^{-1}\right)$ retained on previously weighed filters (for detailed filtration procedures, see the section below titled Total particulate matter (TPM) biomass). These seawater volumes were also used to quantify the cell numbers of various microorganisms (see below). Linear regression between values of turbidity-sensor data (NTU) and actual TPM concentration $\left(\mathrm{g} \mathrm{L}^{-1}\right)$ measured at 6 flow levels was calculated $\left(\mathrm{R}^{2}>0.92\right)$ and used to convert the continuous turbidity-sensor data time series into TPM along the entire erosion experiment. A similar procedure was applied to convert fluorometric sensor data into chl $a$, but using a polynomial regression $\left(\mathrm{R}^{2}=0.99\right)$. Dilution effect of the sampling process was accounted for, since the quantity of water sampled for filtration at 6 successive steps along each erosion experiment was replaced by the same quantity of filtered water in order to adjust to the original total volume in the system.

The mass of eroded sediment was computed as the product of turbidity concentration ( $\mathrm{g}$ $\left.\mathrm{L}^{-1}\right)$ and water volume (15L), divided by the two sediment cores area $\left(=2 \pi \times 0.045^{2} \mathrm{~m}^{2}\right)$. The same calculation was performed to convert chl $a$ concentration in erodimetre seawater to eroded chl $a$ (in $\mu \mathrm{g} \mathrm{m}^{-2}$ ). The rate of erosion of fine particles was deduced from the time derivative of the turbidity curve, after calibration and correction for dilution effects (Sutherland et al. 1998). After the onset of erosion, the net erosion rates were calculated as the differential concentrations of the eroded sediment variables of the water samples divided by the elapsed time and were normalised to unit bed area.

\section{Microprofiles of chlorophyll a}

Cores assigned to microprofile analysis (3 cores) were sub-sampled at the end of emersion in the field using plastic cylinders $(1.5 \mathrm{~cm}$ in diameter, $2 \mathrm{~cm}$ in height) and immediately frozen in liquid nitrogen and stored at $-80^{\circ} \mathrm{C}$. These cores were taken back to the lab and sectioned $(200 \mu \mathrm{m})$ using cryolanding techniques at $-15^{\circ} \mathrm{C}$, in order to define the chl $a$ distribution with depth (every $200 \mu \mathrm{m}$ up to $2000 \mu \mathrm{m}$ depth; 2800-3000 $\mu \mathrm{m}$; 3800-4000 $\mu \mathrm{m}$; $5800-6000 \mu \mathrm{m}$; 7800-8000 $\mu \mathrm{m}$; 9800-10000 $\mu \mathrm{m}$ ). Each section of the sediment was placed in pre-weighed Eppendorf tube and freeze-dried. The dry mass was recorded and chl $a$ concentration was analyzed as described in the section below.

\section{Chlorophyll a analysis}

Chl $a$ was measured using the fluorometric method (Lorenzen, 1966) and expressed as $\mu \mathrm{g}$ chl $a \mathrm{~L}^{-1}$ in the volume of seawater and $\mu \mathrm{g}$ chl $a \mathrm{~g}^{-1}$ for the freeze-dried sediment. To perform fluorometric analyses, erodimetre seawater samples $(10-50 \mathrm{ml})$ were filtered in a 10 
$\mathrm{mm} \mathrm{Hg}$ vacuum onto a $2.5 \mathrm{~cm}$ diameter $\mathrm{GF} / \mathrm{F}$ filter, which was kept at $-20^{\circ} \mathrm{C}$ in Corning glass tubes until extraction. For each depth of the vertical microprofiles, the sediment was recuperated and freeze-dried. For fluorometric analyses, filters or sediments were extracted in $90 \%$ acetone and continuously rotated $(12 \mathrm{rpm})$ for $18 \mathrm{~h}$ in the dark. Concentrations of extracted chlorophyll $a(\operatorname{chl} a)$ was measured using a Fluorometer Turner TD-700.

\section{Total particulate matter (TPM) biomass}

TPM was measured using the method described by Aminot and Chaussepied (1983). Seawater samples from the erodimetre experiments $(100-500 \mathrm{ml})$ were filtered within $1 \mathrm{~h}$ onto a Whatmann GF/C (47 $\mathrm{mm}$ in diameter) under a vacuum pressure of pump $<10 \mathrm{~mm} \mathrm{Hg}$. Filters were previously combusted at $490^{\circ} \mathrm{C}$ for $2 \mathrm{~h}$ to eliminate the organic carbon content and then weighed. After sample filtration, each filter was rinsed twice with distilled water to remove salt, dried at $60^{\circ} \mathrm{C}$ for $12 \mathrm{~h}$ and weighed to measure TPM.

TPM was then converted into eroded volume and thickness of an eroded sedimentary layer $h(t)$ using the bulk density of resuspended TPM $(\rho)$ and core surfaces $(S)$ as follows : $\mathrm{h}(\mathrm{t})=\mathrm{TPM} / 2 \rho \mathrm{S}$. Bulk density of TPM was calculated assuming TPM was a mixture of an organic fraction with density of 1 and an inorganic fraction with a density of 2.7 (pure silicates), accounting for sediment water content.

\section{Enumeration of microorganisms}

For viruses, $3 \mathrm{~mL}$ subsamples were fixed in filtered formaldehyde (final concentration, $2 \%$ ) and stored for less than a day at $4^{\circ} \mathrm{C}$. Samples were filtered onto $0.02 \mu \mathrm{m}$ Anodiscs (25mm, Whatmann) and enumerated using epifluorescence microscopy after staining for 30 min with Sybr Green I (Noble and Fuhrman, 1998). Viruses were counted in at least 15 randomly chosen fields under blue excitation (Zeiss Axioskop 1000x). Only free viruses were enumerated.

For bacteria, $3 \mathrm{~mL}$ subsamples were fixed with filtered formaldehyde (final concentration, $2 \%$ ) and stored for less than a day at $4^{\circ} \mathrm{C}$. Samples were filtered onto $0.02 \mu \mathrm{m}$ Anodiscs (25mm diameter, Whatmann). Samples were enumerated using epifluorescence microscopy after staining for 30 min with Sybr Green I (Noble and Fuhrman 1998). Bacteria were counted in at least 15 fields randomly chosen under blue excitation (Zeiss Axioskop 1000x). Free bacteria and attached bacteria were screened by varying the focus. 
For nanoplanktonic cells, subsamples (20 mL maximum) were fixed, stained, and enumerated according to methods described by Sherr et al. (1994), as modified by Dupuy et al. (1999).

For microbenthic cells (diatoms, dinoflagellates and ciliates), subsamples (50 mL maximum) were stained with alkaline lugol (final concentration, 1\%). Microplanktonic cells were counted in Utermöhl settling chambers (Hydro-Bios combined plate chambers) under an inverted microscope (x 200). Taxonomic determination of microplankton was based on Kahl (1931), Lee (1997), and Ricard (1987).

\section{Data treatment of microprofiles of chlorophyll a}

Bulk density and total depth of the vertical section were used to convert data in $\mathrm{mg} \mathrm{m}^{-2}$ of chl $a$ cumulated over the depth. A 2-order polynomial regression was calculated to fit on the cumulated chl $a$ curve as a function of the depth. By using data of eroded mass and measured volumetric mass, we estimated the depth of eroded sediment assuming a uniform erosion over the surface. We then could extrapolate the chl $a$ quantity of eroded chl $a$ in $\mathrm{mg}$ $\mathrm{m}^{-2}$ associated to the eroded volume of sediment (named after like "predicted resuspended chl a").

\section{Results and discussion}

\section{Resuspension of TPM and microorganisms}

In many coastal and shelf environments, resuspension is a recurrent process, which is driven by bed shear stress intensity and sediment erodibility, and usually decreases with depth according to consolidation status (Thomsen and Gust, 2000). In the literature, many papers mentioned that the TPM into the seawater was due to resuspension of a surficial fluff layer of mineral and organic matter. In the literature, many papers mentioned that at each tide, resuspension occurred but varied with friction velocity $\left(\mathrm{u}^{*}\right)$, the stability of the sediment, the spatial distribution (horizontal and vertical distribution) of microorganisms, the behaviour and size of microorganisms or the association of microorganisms to the sediment.

Variability in core surface roughness leads to different friction velocities for the same discharge. As a consequence, the maximum friction velocity that was reached at the end of erosion experiment for the same maximum discharge varied between dates (Fig. 1).

In our study, TPM started to be eroded at friction velocities $>3 \mathrm{~cm} \mathrm{~s}^{-1}$ (Fig. 1) and the critical friction velocity varied from 3.3 (25 July) to $8.7 \mathrm{~cm} \mathrm{~s}^{-1}$ (23 July) with a mean of $\mathrm{u}^{*}{ }_{\text {crit }}=$ $6.1 \mathrm{~cm} \mathrm{~s}^{-1}$ (Fig. 2A). Chl $a$ was resuspended with the same profile of TPM (Fig.1 and Fig. 2A) 
and the $\mathrm{u}^{*}{ }_{\text {crit }}$ varied from 2.1 (25 July) to $6.3 \mathrm{~cm} \mathrm{~s}^{-1}$ (18 July) with a mean of $\mathrm{u}_{\text {crit }}^{*}=4.8 \mathrm{~cm} \mathrm{~s}^{-1}$ (Fig. 2A). In the field, resuspension generally occurs but with different intensity depending on friction velocity, at average values of $5 \mathrm{~cm} \mathrm{~s}^{-1}$ (Orvain et al., this issue). Figure 1 evidenced gradual erosion curves, with erosion at lower friction velocities on 17, 19, 21, and 22 July experiments as compared with 18, 23, and 24 July. Erosion kinetics (Fig. 1) displayed after a first phase of limited erosion, a subsequent phase of mass erosion for friction velocities larger than $6 \mathrm{~cm} \mathrm{~s}^{-1}$ (except on $25 \mathrm{July,} \mathrm{when} \mathrm{mass} \mathrm{erosion} \mathrm{occurred} \mathrm{for} \mathrm{u}^{*}$ crit $=3.3 \mathrm{~cm} \mathrm{~s}^{-1}$ ). The total eroded volume of sediment at the end of the erosion experiment varied from 0 to $9 \mathrm{~cm}^{3}$ (data not shown) reflecting variability in sediment erodibility between the dates of experiment. Excluding the maximum value of eroded volume that occurred on 25 July during the survey, sediment erodibility was moderate and the eroded volume varied from 0 to $2.5 \mathrm{~cm}^{3}$ (data not shown).

In our study, with increasing friction velocity, viruses, prokaryotes and protists resuspended sequentially rather than simultaneously (Fig.1). Dinoflagellates and ciliates are not presented here because of their very low abundance into the erodimetre water $(<7$ specimens in $50 \mathrm{~mL}$ ), and with presumably low abundance in sediments as well. Indeed, ciliates are more abundant in fine sand (Fenchel, 1969; Epstein, 1995) than in muddy sediment enriched with organic matter (Giere, 1993). But another study and ecosystem, like in Buzzards Bay (Massachusetts), where grain sediment were $<25 \mu \mathrm{m}$ at $15 \mathrm{~m}$ deep, Shimeta et al. (2002) proved the resuspension of ciliates (oligotrich, hypotrich ciliates and scuticociliates): oligotrich ciliates resuspended in weak flow $\left(\mathrm{u}^{*}=0.25-0.8 \mathrm{~cm} \mathrm{~s}^{-1}\right)$, hypotrich ciliates and scuticociliates resuspended in moderate flow $\left(\mathrm{u}^{*}=0.82\right.$ to $\left.1.3 \mathrm{~cm} \mathrm{~s}^{-1}\right)$.

In our study, free viruses, free bacteria and some nanoflagellates, were resuspended first (Fig.1). The $\mathrm{u}^{*}$ crit of nanoflagellates varied from 2.1 (25 July) to $6 \mathrm{~cm} \mathrm{~s}^{-1}$ (18 July) with a mean of $\mathrm{u}^{*}{ }_{\text {crit }}=4.7 \mathrm{~cm} \mathrm{~s}^{-1}$ (Fig. 2B). Shimeta et al. (2002), in subtidal sediment, also found rapid resuspension of heterotrophic nanoflagellates, even at friction velocities between 0.25 $0.65 \mathrm{~cm} \mathrm{~s}^{-1}$. The $\mathrm{u}^{*}$ crit of free viruses varied from 0.39 (18 July) to $4.7 \mathrm{~cm} \mathrm{~s}^{-1}$ (23 July) with a mean of $\mathrm{u}^{*}{ }_{\text {crit }}=2 \mathrm{~cm} \mathrm{~s}^{-1}$ (Fig. 2A). The low resuspension thresholds of free viruses, free bacteria and some nanoflagellates may be due to their loose association with sediment or with an easily eroded fluff layer. A majority of these microorganisms live in the interstitial water (Fenchel, 1969) and at the sediment-water interface (Shimeta and Sisson, 1999). Free viruses abundance in the water column generally increased with friction velocity but erosion kinetics fluctuated between dates. The oscillations of free viruses and notably free bacteria during one experiment may be initially explained (but cannot be proved in this study) by the different 
strength of association with clay particles and desorption into the water and then by the events of re-adsorption of eroded particulate matter in accordance with progressive changes in the composition of the benthic organisms assemblages, with microbial strains more or less resistant to sediment resuspension, and with enhancing changes in contact rates into the running water respectively (Malits and Weinbauer, 2009; Syngouna and Chrysikopoulos, 2010). The mechanism of microbial adsorption to clayed mineral, and desorption, evolved via the clay-cation-microbe bridges, reinforced by the hydrophobic interactions via the antichaotropic effect of $\mathrm{NaCl}$ salt (Gerba 1984) and the water movement according to the Derjaguin-Landau-Verwey-Overbeek (DLVO) theory (Zemb et al, 2013). Moreover, chemical characteristics of the cell walls of bacteria (hydrophobicity) may change due to the stress of the process of erosion.

Like TPM, a second group of microorganisms $(<60 \mu \mathrm{m}$ diatoms (noticeable with chl a), some nanoflagellates and attached bacteria), started to be resuspended at friction velocities $>3 \mathrm{~cm} \mathrm{~s}^{-1}$ (Fig. 1 and Fig. 2). Resuspension of these groups then strongly increased from friction velocities $>5 \mathrm{~cm} \mathrm{~s}^{-1}$. Attached bacteria, started to be eroded for friction velocity ranging from 1 to $3 \mathrm{~cm} \mathrm{~s}^{-1}$. The $\mathrm{u}^{*}$ crit of attached bacteria varied from 1.2 (25 July) to $6.7 \mathrm{~cm}$ $\mathrm{s}^{-1}$ (23 july) with a mean of $\mathrm{u}^{*}$ crit $=4.3 \mathrm{~cm} \mathrm{~s}^{-1}$ (Fig. 2B), similarly to chl $a$. For nanoflagellates and diatoms, Shimeta et al. (2002) found similar results but at a lower friction velocity (e.g. $1.47 \mathrm{~cm} \mathrm{~s}^{-1}$ for pigmented nanoflagellates) at a subtidal site. The difference in erosion thresholds for these micro-organisms found in our study and by Shimeta et al. (2002) should be expected as a result of varying level of sediment erodibility in natural settings. Indeed, it can be expected that subtidal water-saturated sediment is less consolidated than intertidal sediment exposed to regular dessication at low tide. But, in addition, the zonation of microorganisms on the vertical may also be different between the two types of environments (subtidal/intertidal). As a matter of fact, changes in sediment erodibility was clearly evidenced across the mudflat by alternate large and low TPM concentration increase during a Lagrangian field survey (following the flow in a constant water depth) carried out at a rising tide in the presence of waves (Guizien et al., 2013). Meanwhile, during this Lagrangian survey, enrichment in some benthic micro-organisms (virus, bacteria, nanoflagellates, diatoms and ciliates) expected from sediment resuspension under large friction velocities $>3.5 \mathrm{~cm} \mathrm{~s}^{-1}$ induced by waves was masked probably by rapid grazing, absent in the present experimental study.

At a friction velocity $>3 \mathrm{~cm} \mathrm{~s}^{-1}$, chl $a$ resuspended together with TPM $\left(\mathrm{r}^{2}=0.82, \mathrm{p}<\right.$ 0.01 without date of 25 July) (Fig. 2A). Diatom erosion curves (see below) were correlated 
with chl $a$ erosion curves $\left(\mathrm{r}^{2}=0.77, \mathrm{p}<0.01\right)$, indicating that $\mathrm{chl} a$ resuspended into the water column was mainly composed of benthic diatoms. The attached bacteria erosion curve was also correlated to TPM $\left(\mathrm{r}^{2}=0.54, \mathrm{p}<0.1\right.$ without date of $\left.25 \mathrm{July}\right)$ and chl $a\left(\mathrm{r}^{2}=0.63, \mathrm{p}<0.01\right)$ erosion curve. Diatoms and attached bacteria resuspension can be explained by the association with sediment particles and/or the migratory behaviour in response to overlying flow. We know that MPB migrate vertically in response to changes in light (weather or overlying flow) (Herlory et al., 2004).

In the present study, resuspension of diatoms was studied in more detail with respect to their size and taxonomic affiliation. In our study, the resuspended microphytobenthos (MPB) was mainly composed by small Navicula spp. ( $<60 \mu \mathrm{m} ; 23-61 \%$ of total diatom abundance), Surirella sp. (<60 $\mu \mathrm{m} ; 8-57 \%)$ and Pleurosigma spp. (60 $\mu \mathrm{m}$ to $150 \mu \mathrm{m}, 2-15$ $\%)$. Other diatom taxa were rare (Table 1). The above genera are common in sediments; Haubois et al. (2005) found a dominance of the small species Navicula phyllepta throughout the year with a seasonal succession of secondary species, including only one large diatom (Gyrosigma peisonis) in Brouage mudflat. Underwood (2010) found a dominance of Navicula and Nitzschia spp. in Severn estuary (UK), and Sahan et al. (2007) mainly found Navicula spp. in Westerschelde estuary (the Netherlands). In our study, diatoms $<60 \mu \mathrm{m}$ resuspended at friction velocities between 3 and $5 \mathrm{~cm} \mathrm{~s}^{-1}$, and diatoms $>60 \mu \mathrm{m}$ at friction velocities between 5.5 and $6.5 \mathrm{~cm} \mathrm{~s}^{-1}$ (Fig. 1) with a $\mathrm{u}^{*}$ crit $=3.5$ to $6.8 \mathrm{~cm} \mathrm{~s}^{-1}$ with a mean of $5.3 \mathrm{~cm} \mathrm{~s}^{-1}$ for all the size of diatoms (Fig. 2B). Shimeta et al. (2002) found resuspension at low to moderate friction velocities for $<60 \mu \mathrm{m}$ diatoms, Navicula distans $\left(0.40-0.80 \mathrm{~cm} \mathrm{~s}^{-1}\right)$, Navicula transitans (0.90-1.25 $\left.\mathrm{cm} \mathrm{s}^{-1}\right)$, Pleurosigma sp. (1.23-1.30 $\left.\mathrm{cm} \mathrm{s}^{-1}\right)$, and two Nitzschia species $\left(1.58 \mathrm{~cm} \mathrm{~s}^{-1}\right)$. The explanation for this may be the same as that for nanoflagellates in the same study (Shimeta et al. 2002), i.e., that subtidal water-saturated sediment is less consolidated than intertidal sediment and the zonation of microorganisms on the vertical was different between the two types of environments.

On 25 July, mass erosion occurred at a very low shear velocity $\left(\sim 2.5 \mathrm{~cm} \mathrm{~s}^{-1}\right)$ because of a drastic decrease of bed resistance to erosion (Fig.1 and Fig.2). Indeed, the erosion curve on 25 July was different with a rapid increase of TPM during the experiment (Fig. 1). On this same date, resuspension for free viruses and bacteria, and nanoflagellates, was clearly higher and started at lower friction velocities (Fig. 1 and Fig. 2B). Attached bacteria were also rapidly and intensively resuspended, together with TPM. The control of sediment erodibility by biofilm factors is analysed in more details in Orvain et al. (this issue). But, the probable major factor was the presence of gastropod, Peringia ulvae, a deposit-feeder and a bioturbator 
of the surface of the sediment, which can bulldoze the surface so drastically that the distribution of MPB, and thus other microorganisms and the biofilm matrix, is disturbed, along with their resuspension flux (Fig. 5) (Orvain et al. 2004).

To summarise, the thresholds of resuspension, in this study, depend on the type, size, and behaviour of microorganisms, as well as the association of microorganisms to the sediment. But the thresholds of resuspension can also depend on the micro-scale position of microorganisms in the sediment (horizontal and vertical distribution).

\section{Possible view of spatial distribution of $M P B$}

The distribution of chl $a$ was not homogeneous in the sediment (vertical position). Chl $a$ was mainly present in the first $2 \mathrm{~mm}$ below the sediment surface (Fig. 3), in accordance with Herlory et al. (2004) and Mitbavkar and Anil (2004). The vertical distribution of Chl $a$ exhibited an exponential decline with depth (Fig. 3), as in Herlory et al. (2004), Du et al. (2010), and Underwood (2010).

At the surface of the sediment, the biomass of chl $a$ increased from 17 July to 23 July (58 $\pm 6.9 \mu \mathrm{g} \mathrm{g}^{-1} \mathrm{dw}$ sed) and then decreased again $\left(28 \mu \mathrm{g} \mathrm{g}^{-1} \mathrm{dw}\right.$ sed). The maximal chl $a$ biomass at the surface of sediment was registered on 23 July just after the maximum emersion duration corresponding to maximum daylight (Fig. 3). Such a response to exposure duration of the typical $15 \mathrm{~d}$ spring/neap cycle (spring tides being the conditions with the longest lowtide exposure periods around the maximum daylight) is a classical scheme for MPB dynamics in which biomass increases during exposure time lags (Blanchard et al. 2001; Orvain el al., 2012) and decreases when the exposure time decreases.

Figure 4 represents the relationship between the predicted resuspended chl $a$ based on distribution of chl $a$ into the sediment (microprofiles of chl $a$ ) and sediment eroded depth versus observed chl $a$ in the erodimetre water column. Different cases can be considered: 1) if the slope is equal to 1 , the measured erosion corresponds to the predicted erosion, corresponding to a homogeneous horizontal distribution of chl $a$ in the sediment and a uniform erosion of the sediment cores; 2) if the slope is $<1$, the erodimetre water is poorer in chl $a$ than expected from chl $a$ microprofiles assuming horizontally uniform erosion (erosion of sediment poorer in chl $a$ than in microprofiles at average eroded depth); and 3) if the slope is $>1$, the erodimetre water is richer in chl $a$ than expected from chl $a$ microprofiles assuming horizontally uniform erosion (erosion of sediment richer in chl $a$ than in microprofiles at average eroded depth). The data showed that the slope varied with dates (Fig. 4). Erosion was uniform during the first days (slope=1 in 17 July and 19 July) or displayed preferential 
erosion of high chl $a$ patches (slope >1) in 18 July. After 20 July, erosion pattern shifted and preferentially affected low chl $a$ zones (slope $<1$, (Fig. 4A)). The slope was the lowest at 25 July when sediment erodibility was maximum (Fig. 4B). In other words, while the biomass of chl $a$ increased at the surface $(2 \mathrm{~mm})$ from 17 to 23 July, the distribution of chl $a$ seems relatively homogeneous on the sediment surface (from 5 to $11 \%$ of variation of chl $a$ in the surface, but $29 \%$ in 17 July, Fig. 3), and uniformly erodible at the very beginning of biofilm growth but most probably developed in patch on the horizontal surface of the sediment after a few days (July 20 and after, from 12 to $29 \%$ of variation of chl $a$ in the surface, Fig. 3). Patches could also have resulted from the high density of grazing snails, creating a biogenic fluff layer depleted chl a (Orvain et al., 2007; Orvain et al., this issue). At the end of the experiments, erosion patterns indicated that erosion affected preferentially those low chl $a$ zones, which could indicate that bioturbation destabilised sediment surface and regulated by changes in terms of MPB coverage and self-organization of benthic diatoms in the biofilm (Fig.5) as demonstrated Weerman et al. (2012), who indicated a gradual failure in time of the self-organization process that underlies regular patterning. With this study, we have no real data on horizontal distribution and very few informations was available about this horizontal spatial distribution at micro-scale of the MPB: Herlory et al. (2004) demonstrated that the biomass at low tide contained in the top $1 \mathrm{~mm}$ was concentrated in the upper $200 \mu \mathrm{m}$, but the cover never reached $100 \%$ (maximum of $70 \%$ to $80 \%$ of the surface). The MPB have a high degree of spatial heterogeneity in biomass (Paterson et al., 2000; Underwood, 2010). Selforganisation of biofilm in terms of microhetetogeneity was very important to better understand the effects on erosion (Weerman et al., 2012) and we clearly identify that interaction effects between microphytobenthos and macrozoobenthos species can control chl $a$ erosion rates, by modifying patchiness patterns. More studies need to be performed in this area.

In this study, it was not possible to extend this argument to other microorganisms studied, but it has been reported that nanobenthos densities can display a vertically stratified distribution with values 2 to 3 times lower in deep sediment (30 to 33 and 60 to $63 \mathrm{~mm}$ ) than in the sediment surface layer (0 to $3 \mathrm{~mm}$ ) (Bak and Nieuwland, 1989). Heterogeneous vertical distribution has also been reported for bacteria with maximum values at the sediment water interface, decreasing in the first $\mathrm{cm}$ and stabilising down to 15 to $25 \mathrm{~cm}$ depth (Drake et al., 1998), or from 0 to $40 \mathrm{~mm}$ in the coastal sediments of the German Wadden Sea (Brinkhoff et al., 1998). No data are available for sediment viruses, but in a temperate mangrove estuary, viruses were concentrated in the 1 to $2 \mathrm{~cm}$ immediately above the sediment surface (Seymour 
et al., 2006). Horizontal and vertical distribution of benthic viruses still remains to be explored.

\section{Conclusion}

This study measured resuspension thresholds of viruses, prokaryotes and protists at an intertidal mudflat with a mobile erosion device. This study reported the first data concerning the resuspension of viruses at an intertidal mudflat. Free microorganisms (viruses, bacteria and some nanoflagellates) resuspended at weak flow $\left(\mathrm{u}^{*}\right.$ crit $\left.<2 \mathrm{~cm} \mathrm{~s}^{-1}\right)$. Microphytobenthos, some nanoflagellates and attached bacteria resuspended at higher flow $\left(\mathrm{u}^{*}{ }_{\mathrm{crit}}>3 \mathrm{~cm} \mathrm{~s}^{-1}\right)$. The difference of thresholds was due first to association with particles of sediment, i.e., free microorganisms and viruses were likely to be free in interstitial water while microphytobenthos, some nanoflagellates and attached bacteria microorganisms resuspended with bulk sediment in relation to biotic interactions. Secondly, the sequential resuspension varied with the size of microorganisms. In our study, $<60 \mu \mathrm{m}$ diatoms resuspended at friction velocities from 3 to $5 \mathrm{~cm} \mathrm{~s}^{-1}$, and $>60 \mu \mathrm{m}$ diatoms resuspended at friction velocities from 5.5 to $6.5 \mathrm{~cm} \mathrm{~s}^{-1}$. The erosion experiments reflected the possible patchy distribution of chl $a$ on the horizontal surface of the sediment, determined by calculation. During the 8 erosion experiments, homogeneous horizontal distribution of chl $a$ and thus of erosion was only observed during two days, at the very beginning of biofilm growth. In the other days, erosion mainly affected areas with low chl $a$ content, which was most likely explained by the intense grazing activity of snails in MPB patches, which destabilised the sediment. But our study did not prove this real horizontal distribution, and new data need to be acquired to really affirm this conclusion.

\section{Acknowledgements}

This study was supported by the French ANR (National Research Agency) through the VASIREMI project “Trophic significance of microbial biofilms in tidal flats" (contract ANR420 06-BLAN-0393-01). We are also grateful to anonymous reviewers and Proofreading.com for English corrections.

\section{References}

Aminot, A., Chaussepied, M., 1983. Manuel des analyses chimiques en milieu marin. CNEXO, Brest. 
Andersen, T.J., Lanaru, M., van Bernem, C., Pejrup, M., Riethmueller, R., 2010. Erodability of a mixed mudflat dominated by microphytobenthos and Cerastoderma edule, East Frisian Wadden Sea, Germany. Estuarine Coastal and Shelf Science 87, 197-206.

Austen, I., Andersen, T.J., Edelvang, K., 1999. The influence of benthic diatoms and invertebrates on the erodibility of an intertidal mudflat, the Danish Wadden Sea. Estuarine Coastal and Shelf Science 49, 99-111.

Bassoulet, P., Le Hir, P., Gouleau, R., Robert, S., 2000. Sediment transport over an intertidal mudflat: field investigations and estimation of fluxes within the "Baie de Marennes-Oléron" (France) Continental Shelf Research 20, 1635-1653.

Bak, R.P.M., Nieuwland, G., 1989. Seasonal fluctuations in benthic protozoan populations at different depths in marine sediments Netherlands Journal of Sea Research 24, 37-44.

Blanchard, G.F., Cariou-Le Gall, V., 1994. Photosynthetic characteristics of microphytobenthos in Marennes-Oleron Bay, France: Preliminary results. Journal Experimental Marine Biology and Ecology 182, 1-14.

Blanchard G. F., Sauriau, P-G, Cariou-Le Gall, V., Gouleau, D., Garet, M-J, Olivier, F., 1997. Kinetics of tidal resuspension of microbiota : Testing the effects of sediment cohesiveness and bioturbation using flume experiments. Marine Ecology Progress Series 151, 17-25.

Blanchard, G.F., Guarini, J.M., Provot, L., Richard, P., Sauriau, P.G., 2000. Measurement of ingestion rate of Hydrobia ulvae (Pennant) on intertidal epipelic microalgae: the effect of mud snail density. Journal Experimental Marine Biology and Ecology 255, 247-260.

Blanchard, G.F., Guarini, J.M., Orvain, F., Sauriau, P.G., 2001. Dynamic behaviour of benthic microalgal biomass in intertidal mudflat. Journal Experimental Marine Biology and Ecology 264, 85-100.

Breitbart, M., Felts, B., Kelley, S., Mahaffy, J., Nulton, J., Salamon, P., and Rohwer, F., 2004. Diversity and population structure of a near-shore marine-sediment viral community. Proc. R. Soc. Lond. B 271, 565-574.

Brinkhoff, T., Santegoeds, C.M., Sahm, K., Kuever, J., Muyzer, G., 1998. A Polyphasic Approach to Study the Diversity and Vertical Distribution of Sulfur-Oxidizing Thiomicrospira Species in Coastal Sediments of the German Wadden Sea. Applied and Environmental Microbiology 64, 4650-4657. 
Brotas, V., Cabrita, T., Portugal, A., Serôdio, J., Catarino, F., 1995. Spatio-temporal distribution of the microphytobenthic biomass in intertidal flats of Tagus Estuary (Portugal). Hydrobiologia 300-301, 93-104.

Christiansen, C., Vølund, G., Lund-Hansen, L.C., Bartholdy, J., 2006. Wind influence on tidal flat sediment dynamics: Field investigations in the Ho Bugt, Danish Wadden Sea. Marine Geology 235, 75-86.

De Backer A., Van Colen, C., Vincx, M., Degraer, S., 2010. The role of biophysical interactions within the Yzermonding tidal flat sediment dynamics. Continental Shelf Research 30, 1166-1179.

Decho, A.W., 2000. Microbial biofilms in intertidal systems: an overview. Continental Shelf Research 20, 1257-1273.

De Jonge, V.N., Colijn, F., 1994. Dynamics of rnicrophytobenthos biomass in the Ems estuary. Marine Ecology Progress Series 104, 185-196.

de Brouwer, J.F.C., Bjelic S., de Deckere E.M.G.T., Stal L.J., 2000. Interplay between biology and sedimentology in a mudflat (Biezelingse Ham, Westerschelde, The Netherlands). Continental Shelf Research 20, 1159-1177.

de Brouwer, J.F.C., Wolfstein, K., Ruddy, G.K., Jones, T.E.R., Stal, L.J., 2005. Biogenic stabilization of intertidal sediments: the importance of extracellular polymeric substances produced by benthic diatoms. Microbial Ecology 49, 501-512.

Drake, L.A., Choil, K.H., Haske, A.G.E., Dobbs, F.C., 1998. Vertical profiles of virus-like particles and bacteria in the water column and sediments of Chesapeake Bay, USA. Aquatic Microbial Ecology 16, 17-25.

Du, G.Y., Son M., An S., Chung, I.K., 2010. Temporal variation in the vertical distribution of microphytobenthos in intertidal flats of the Nakdong River estuary, Korea. Estuarine Coastal and Shelf Science 86, 62-70.

Dupuy, C., Le Gall, S., Hartmann, H.J., Bréret, M., 1999. Retention of ciliates and flagellates by the oyster Crassostrea gigas in French Atlantic coastal ponds: protists as a trophic link between bacterioplankton and benthic suspension-feeders. Marine Ecology Progress Series $177,165-175$. 
Fenchel, T., 1969. The ecology of marine microbenthos IV. Structure and function of the benthic ecosystem, its chemical and physical factors and the microfauna communities with special reference to the ciliated protozoa. Ophelia $6,1-182$.

Garstecki, T., Wickham, S.A., Arndt H., 2002. Effects of Experimental Sediment Resuspension on a Coastal Planktonic Microbial Food Web. Estuarine Coastal and Shelf Science $55,751-762$.

Gasol, J.M., 1993. Benthic Flagellates and Ciliates in Fine Freshwater Sediments: Calibration of a Live Counting Procedure and Estimation of Their Abundances. Microbial Ecology 25, 247-262.

Gerba, C. P., 1984. Applied and theoretical aspects of virus adsorption to surfaces, 30: 133168. In Advances in Applied microbiology [ed.], Academic press, Inc.

Giere, O., 1993. Meiobenthology. The microscopic fauna in aquatic sediments, $328 \mathrm{pp}$.

Guizien, K., Orvain, F., Duchêne, J.C., Le Hir, P., 2012. Accounting for Rough Bed Friction Factors of Mud Beds as a Result of Biological Activity in Erosion Experiments. Journal of Hydraulic Engineering 138, 979-984.

Guizien K., Dupuy C., Ory P., Montanie H., Hartmann H., Chatelain M., Karpytchev M., 2013. Benthic/pelagic coupling: in situ microorganism enrichment of the water column over the Brouage mudflat (French Atlantic coast). In press Journal of Marine Systems

Epstein, S.S., 1995. Simultaneous enumeration of protozoa and micrometazoa from marine sandy sediments. Aquatic Microbial Ecology 9, 219-227.

Haubois, A.G., Sylvestre, F., Guarini, J.M., Richard, P., Blanchard, G.F., 2005. Spatiotemporal structure of the epipelic diatom assemblage from an intertidal mudflat in MarennesOléron Bay, France, Estuarine Coastal and Shelf Science 64, 385-394.

Herlory, O., Guarini, J. M., Richard, P., Blanchard G.F., 2004. Microstructure of microphytobenthic biofilm and its spatio-temporal dynamics in an intertidal mudflat (Aiguillon Bay, France). Marine Ecology Progress Series 282, 33-44.

Herman, P.M.J., Middelburg, J.J., Heip, C.H.R., 2001. Benthic community structure and sediment processes on an intertidal flat: results from the ECOFLAT project. Continental Shelf Research 21 (18-19), 2055-2071.

Honeywill, C., Paterson, D.N., Hagerthey, S.E., 2002. Determination of microphytobenthic 
biomass using pulse-amplitude modulated minimum fluorescence. European Journal Phycology 37, 485-492.

Kahl, A., 1931. Urtiere oder protozoa. In Dahl, F, Dahl, M, Bischoff, H (eds.) Die Tierwelt Deutschlands und der angrenzenden Meeresteile. (J Gustav Fischer, Ed.).

Koh, C.H., Khim, J.S., Araki, H., Yamanishi, H., Mogi, M., Koga, K., 2006. Tidal resuspension of microphytobenthic chlorophyll a in a Nanaura mudflat, Saga, Ariake Sea, Japan: flood-ebb and spring -neap variations. Marine Ecology Progress Series 312, 85-100.

Lee, J., Hutner, S., Bovee, E., 1985. An illustrated Guide to the Protozoa (S of Protozoologists, Ed.).

Le Hir, P., Cann, P., Jestin, H., and Bassoulet, P., 2006. Instrumentation légère pour la mesure de l'érodabilité des sédiments vaseux ou sablovaseux." Proc. IXémes Journées Nationales Génie Côtier-Génie Civil, PARALIA, Nantes, France (in French).

Lorenzen, C.J., 1966. A method for the continuous measurement of in vivo chlorophyll concentration. Deep-Sea Research 13, 223-227.

Lucas, C.H., J. Widdows, M. D. Brinsley, P. N. Salkeld, Herman, P.M.J., 2000. Benthic pelagic exchange of microalgae at a tidal flat. 1. Pigment analysis. Marine Ecology Progress Series 196, 59-73.

MacIntyre, H.L., Geider, R.J., Miller, D.C., 1996. Microphytobenthos: the ecological role of the 'secret garden' of unvegetated, shallow-water marine habitats. 1. Distribution, abundance and primary production. Estuaries 19, 186-201.

Malits, A., Weinbauer, M.G., 2009. Effect of turbulence and viruses on prokaryotic cell size, production and diversity. Aquatic Microbial Ecology 54, 243-254.

Mallet, C., Agogué, H., Bonnemoy, F., Guizien, K., Orvain, F., Dupuy, C., 2013. Community structure of resuspended benthic 1 prokaryotes and their hydrolytic enzymatic activities associated to intertidal mudflat biofilms: an experimental approach. This issue, in Journal of Sea Research.

Méléder, V., Barillé, L., Rincé, Y., Morançais, M., Rosa, P., Gaudin P., 2005. Spatio-temporal changes in microphytobenthos structure analysed by pigment composition in a macrotidal flat (Bourgneuf Bay, France). Marine Ecology Progress Series 297, 83-99. 
Mitbavkar, S., Anil, A.C., 2004. Vertical migratory rhythms of benthic diatoms in a tropical intertidal sand flat: influence of irradiance and tides. Marine Biology 145, 9-20.

Miller, D.C, Geider, R.J., Hugh L. MacIntyre, H.L., 1996. Microphytobenthos: The ecological role of the "secret garden" of unvegetated, shallow-water marine habitats. II. role in sediment stability and shallow-water food webs. Estuaries 19, 202-212.

Montserrat, F., Van Colen, C., Degraer, S., Ysebaert, T., Herman, P.M.J., 2008. Benthic community-mediated sediment dynamics. Marine ecology progress series 372, 43-59.

Noble, R.T., Fuhrman, J.A., 1998. Use of SYBR Green I for rapid epifluorescence counts of marine viruses and bacteria. Aquatic Microbial Ecology 14, 113-118.

Orvain, F., Sauriau, P.G., Sygut, A., Joassard, L., Le Hir, P., 2004. Interacting effects of Hydrobia ulvae bioturbation and microphytobenthos on the erodibility of mudflat sediments. Marine Ecology Progress Series 278, 205-223.

Orvain, F., Sauriau, P.G., Le Hir, P., Guillou, G., Cann, P., Paillard, M., 2007. Spatio-temporal variations in intertidal mudflat erodability: Marennes-Oléron Bay, western France. Continental Shelf Research 27, 1153-1173.

Orvain F., Lefebvre, S., Montepini, J., Sébire, M., Gangnery, A., Sylvand, B., 2012. Spatial and temporal interaction between sediment and microphytobenthos in a temperate estuarine macro-intertidal bay. Marine Ecology Progress Series 458, 53-68.

Orvain, F., Guizien, K.,Lefebvre, L., Bréret, M., Dupuy, C., 2013. Relevance of macrozoobenthic grazers to understand the dynamic behavior of sediment erodibility and microphytobenthos resuspension in sunny summer conditions. This issue, in Journal of Sea Research.

Pascal, P.Y., Dupuy, C., Richard, P., Mallet, C. Armynot du Châtelet, E., Niquil, N., 2009. Seasonal variation in consumption of benthic bacteria by meio- and macrofauna in an intertidal mudflat. Limnology and Oceanography 54, 1048-1059.

Paterson, D.M., 1986. The migratory behaviour of diatom assemblages in a laboratory tidal micro-ecosystem examined by low temperature scanning electron microscopy. Diatom Research 1, 227-239.

Paterson, D.M., 1989. Short-term changes in the erodibility of intertidal cohesive sediments related to the migratory behaviour of epipelic diatoms. Limnology and Oceanography 34, 223-234. 
Paterson, D.M., Tolhurst, T.J., Kelly, J.A., Honeywill, C., Deckere, E.M.G.., Huet, V., Shayler, S.A., Black, K.S., de Brouwer, J.D., Davidson, I., 2000. Variations in sediment properties, Skeffling mudflat, Humber Estuary, UK. Continental Shelf Research 20, 1373-1396.

Ricard, M., 1987. Atlas du phytoplancton marin, vol. 2. (CNRS, Eds.). Paris.

Sahan, E., Sabbe, K., Creach, V., Hernandez-Raquet, G., Vyverman, W., Stal, L.J., Muyzer, G., 2007. Community structure and seasonal dynamics of diatom biofilms and associated grazers in intertidal mudflats. Aquatic Microbial Ecology 47, 253-266.

Sauer, J., Wenderoth, K., Maier, U.G., Rhield, E., 2002. Effects of salinity, light and time on the vertical migration of diatom assemblages. Diatom Research 17, 189-203.

Serôdio, J., Vieira, S., Barroso, F., 2007. Relationship of variable chlorophyll fluorescence indices to photosynthetic rates in microphytobenthos. Aquatic Microbial Ecology 49, 71-85.

Seymour, J.R., Seuront, L., Doubell, P.M., Waters, R.L., Mitchell, J.G., 2006. Microscale patchiness of virioplankton. Journal of Marine Biology Association United Kingdom 86, 551561.

Sherr, E. B., Caron, D. A., Sherr, B.F., 1994. Staining of heterotrophic protists for visualisation via epifluorescence microscopy. In: Kemp, PF, Sherr, BF, Sherr, EB, Cole, JJ [ed.], 213-227.Handbook of Methods in Aquatic Microbial Ecology. Lewis Publishers, Boca Raton, FL.

Shimeta, J., Sisson, J.D., 1999. Taxon-specific tidal resuspension of protists into the subtidal benthic boundary layer of a coastal embayment. Marine Ecology Progress Series 177, 51-62.

Shimeta, J., Amos, C.L, Beaulieu, S.E., Ashiru, L.M., 2002. Sequential Resuspension of Protists by Accelerating Tidal Flow: Implications for Community Structure in the Benthic Boundary Layer. Limnology and Oceanography 47, 1152-1164.

Shimeta, J., Amos, C.L., Beaulieu, S. E., Katz, S.L., 2003. Resuspension of benthic protists at subtidal coastal sites with differing sediment composition. Marine Ecology Progress Series $259,103-115$.

Sutherland, T.F., Grant, J., Amos, C.L., 1998. The effect of carbohydrate production by the diatom Nitzschia curvilineata on the erodibility of sediment. Limnology and Oceanography $43,65-72$. 
Syngouna, V.I., Chrysikopoulos, C.V., 2010. Interaction between viruses and clays in static and dynamic bacth system. Environmental Sciences Technology 44, 4539-4544.

Thomsen, L., Gust, G., 2000. Sediment erosion thresholds and characteristics of resuspended aggregates on the western European continental margin. Deep-Sea Research 47, 1881-1897.

Underwood, G.J.C., Kromkamp, J., 1999. Primary production by phytoplankton and microphytobenthos in estuaries. Advances Ecology Research 29, 93-153.

Underwood, G.J.C., Paterson, D.M., Parkes, R.J., 1995. The measurement of microbial carbohydrate exopolymers from intertidal sediments. Limnology and Oceanography 40, $1243-1253$.

Underwood, G.J.C., 2010. Microphytobenthos and phytoplankton in the Severn estuary, UK: Present situation and possible consequences of a tidal energy barrage. Marine Pollution Bulletin 61, 83-91.

Van Colen, C., Montserrat, F., Vincx, M., Herman, P.M.J., Ysebaert, T., Degraer, S., 2008. Macrobenthic recovery from hypoxia in an estuarine tidal mudflat. Marine ecology progress series 372, 31-42.

Van Colen, C., Rossi, F., Montserrat, F., Andersson, M.A., Gribsholdt, B., Herman, P.M.J., Degraer, S., Vincx, M., Ysebaert, T., Middelburg, J.J., 2012. Organism-sediment interactions govern post-hypoxia recovery of ecosystem functioning. PLoS ONE 7(11):e49795.

Weerman, E. J., Van Belzen, J., Rietkerk, M., Temmerman, S., Kefi, S., Herman, P.M.J., Van De Koppel, J., 2012. Changes in diatom patch-size distribution and degradation in a spatially self-organized intertidal mudflat ecosystem. Ecology 93, 608-618.

Wu, Q.L., Chen, Y., Xu, K., Liu, Z., Hahn, W.N., 2007. Intra-habitat heterogeneity of microbial food web structure under the regime of eutrophication and sediment resuspension in the large subtropical shallow Lake Taihu, China. Hydrobiologia 581, 241-254.

Zemb, O., Manefield, M., Thomas, F., Jacquet, S., 2013. Phage adsorption to bacteria in the light of the electrostatics: A case study using E. coli, T2 and flow cytometry. Journal of Virological Methods 189, 283-289. 
Figure 1: Concentrations of TPM $\left(\mathrm{mg} \mathrm{L}^{-1}\right), \mathrm{Chl} a\left(\mu \mathrm{g} \mathrm{L}^{-1}\right)$ and resuspended microorganisms (cells $\mathrm{L}^{-1}$ or cells $\mathrm{mL}^{-1}$ ) in erodimeter experiments in relation to threshold friction velocity $\left(\mathrm{u}^{*}\right.$ $\mathrm{cm} \mathrm{s}^{-1}$ ) for different dates (17, 18, 19, 21, 22, 23, 24, and 25 July).

Figure 2: Critical friction velocity $\left(\mathrm{u}^{*}{ }_{\mathrm{crit}}, \mathrm{cm} \mathrm{s}^{-1}\right)$ for different dates $(17,18,19,21,22,23,24$, and 25 July) for A) total particulate matter (TPM) and Chlorophyll a (chl $a$ ), and for B) each type of microorganisms (when the calculation was possible).

Figure 3: Chl $a\left(\mu \mathrm{g} \mathrm{g}^{-1} \mathrm{DW}\right.$ sed, mean $\left.\pm \mathrm{SD}, \mathrm{n}=3\right)$ profiles with depth ( $\left.\mathrm{mm}\right)$ at the end of tidal emersion before A) 17, 18, 19, and 21 July and after B) 22, 23, 24, and 25 July spring tide.

Figure 4: Relation between resuspended $\operatorname{chl} a\left(\mathrm{mg} \mathrm{m}^{-2}\right)$ in the erodimeter water and extrapolation of eroded chl $a$ based on chl $a$ profiles in the sediment and eroded TPM (mg m$\left.{ }^{2}\right)$, A) for all the dates (17, 18, 19, 21, 22, 23, and 24 July) except 25 July, B) for all the dates including 25 July. The solid line represents the 1:1 line

Figure 5: Relation between slope of curves of Figure 4 (resuspended chl $a\left(\mathrm{mg} \mathrm{m}^{-2}\right)$ in the erodimeter water versus extrapolation of eroded chl $a$ based on chl a profiles in the sediment and eroded TPM $\left(\mathrm{mg} \mathrm{m}^{-2}\right.$ ) and density of Peringia ulvae (ind $\mathrm{m}^{-2}$ ); labels correspond to sampling date. 


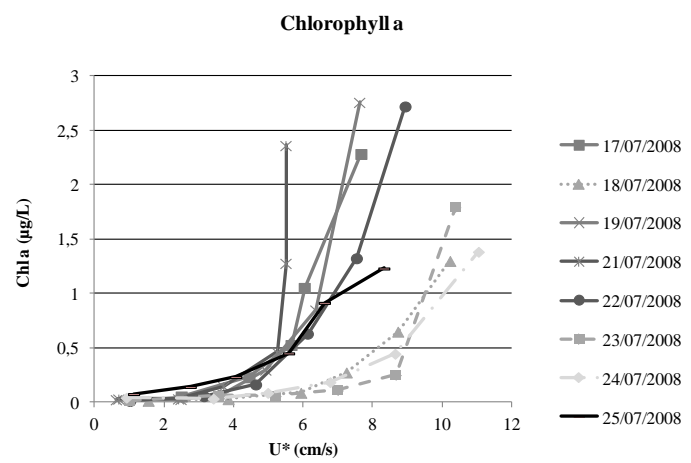

Diatoms $<60 \mu \mathrm{m}$

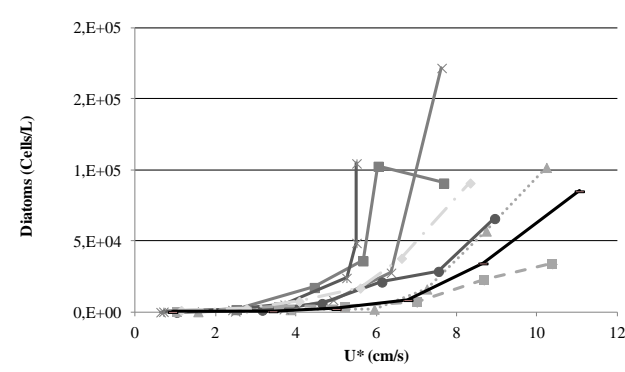

Free virus
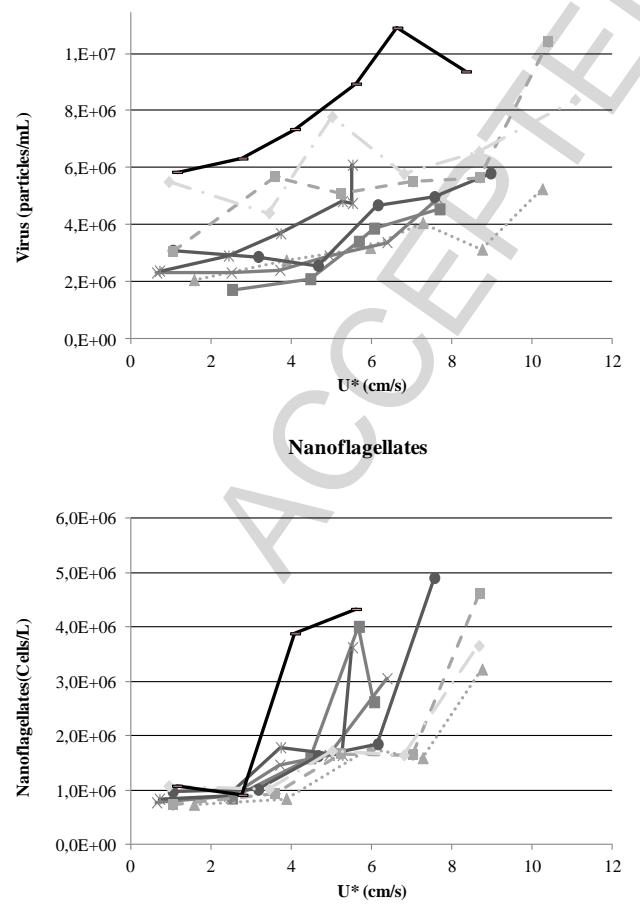

Figure 1:

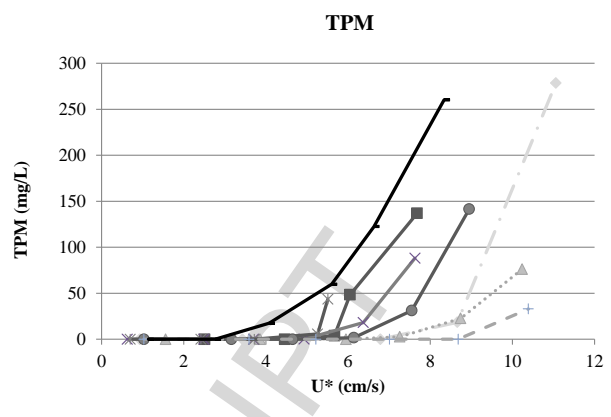

Diatoms $>60 \mu \mathrm{m}$
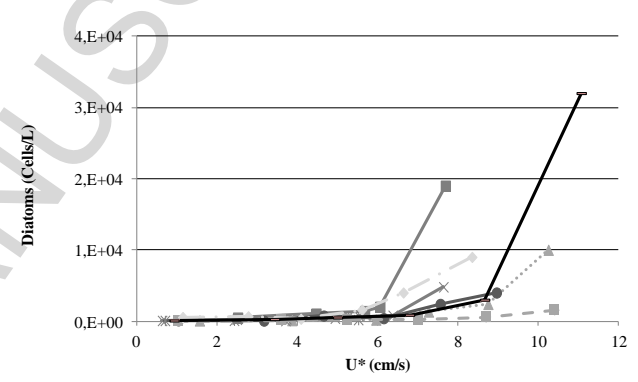

Free bacteria

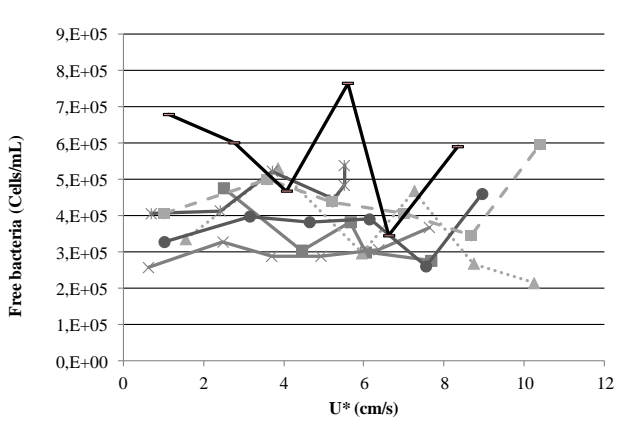

Attached bacteria

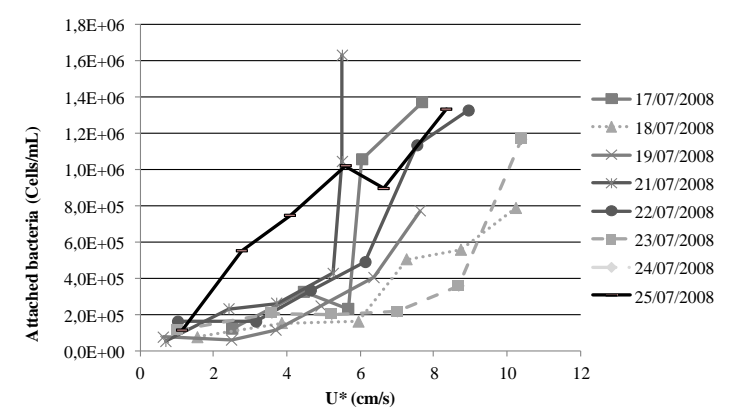


A

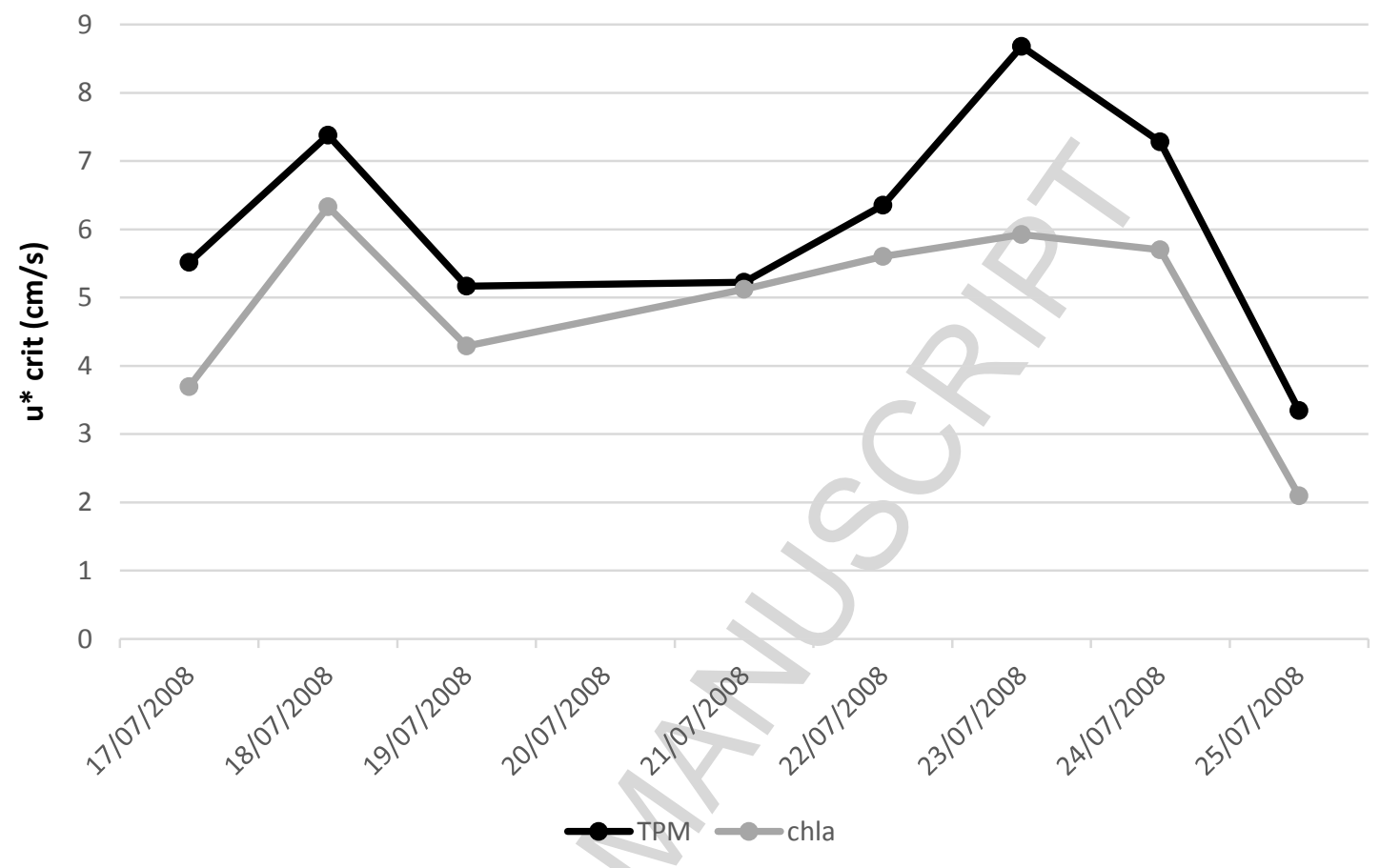

B

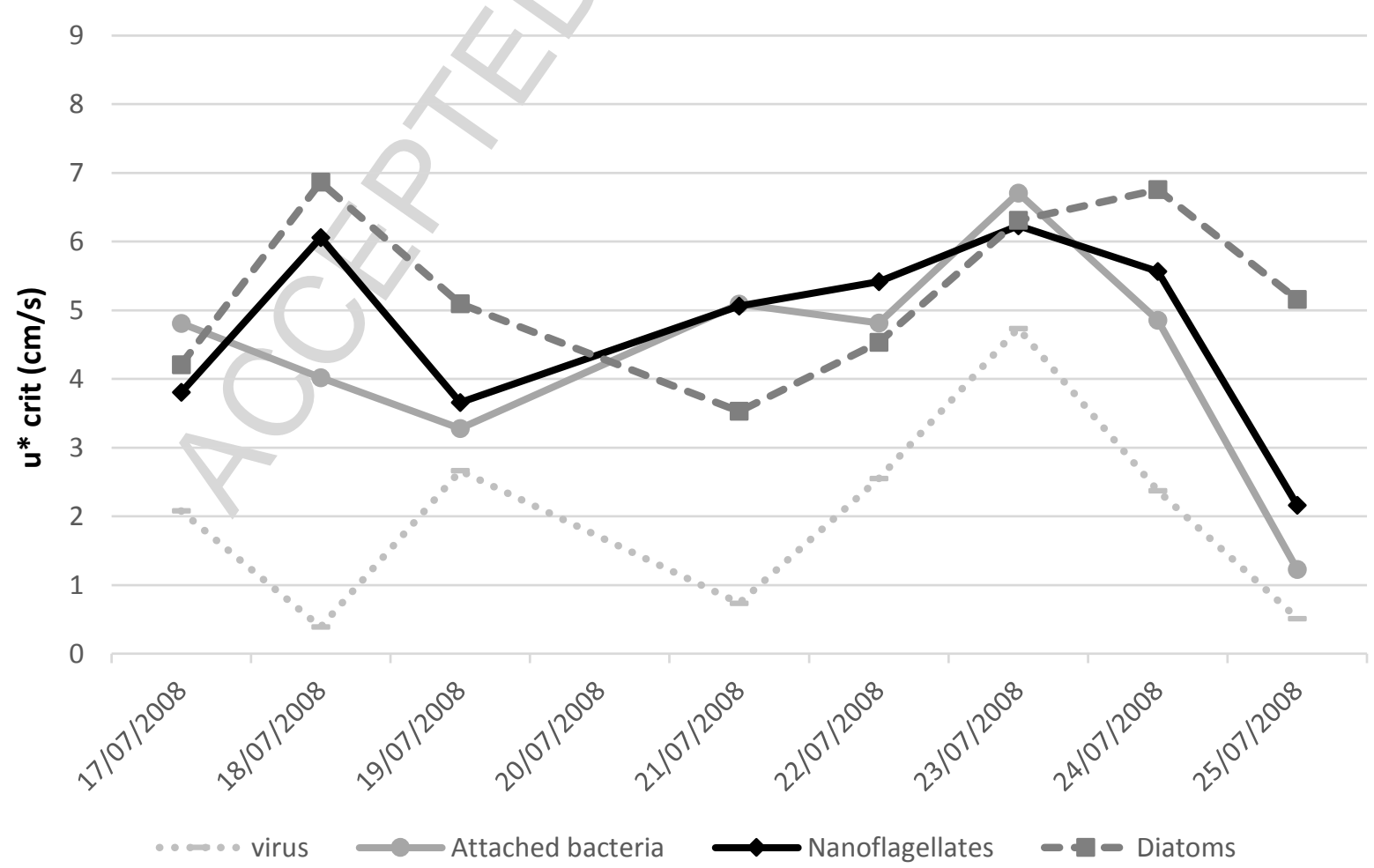

Figure 2: 
A

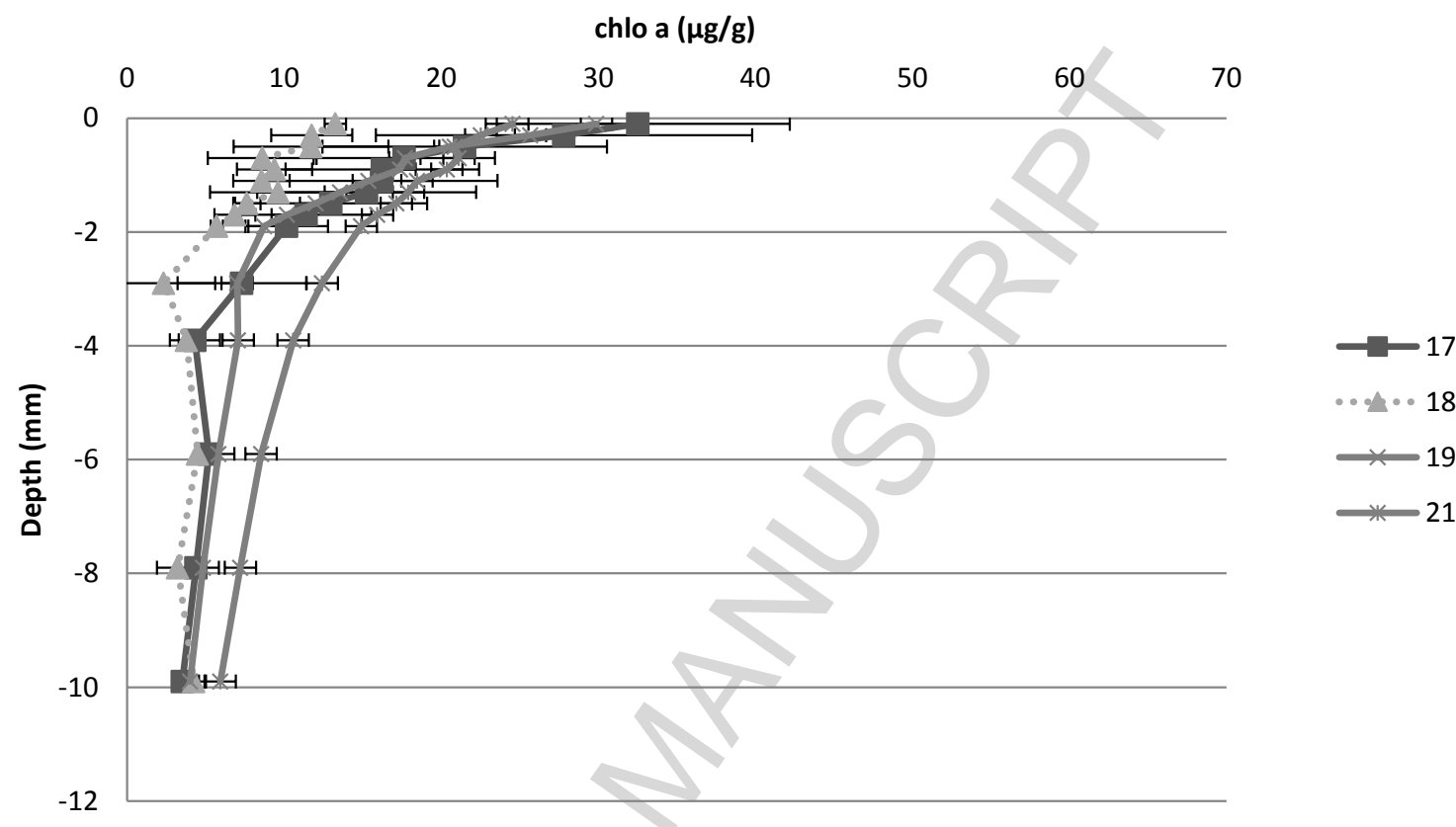

B

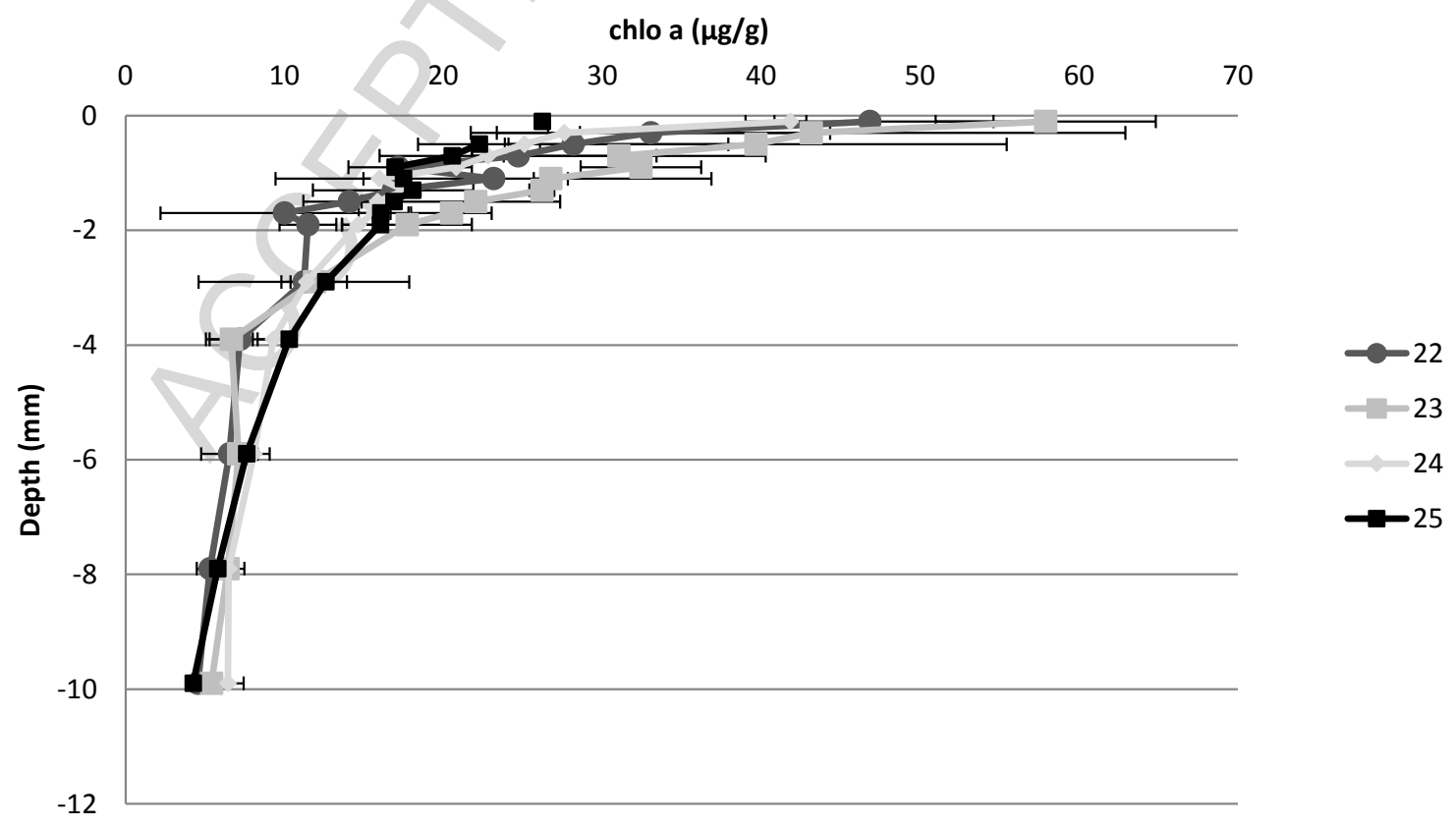

Figure 3: 
A

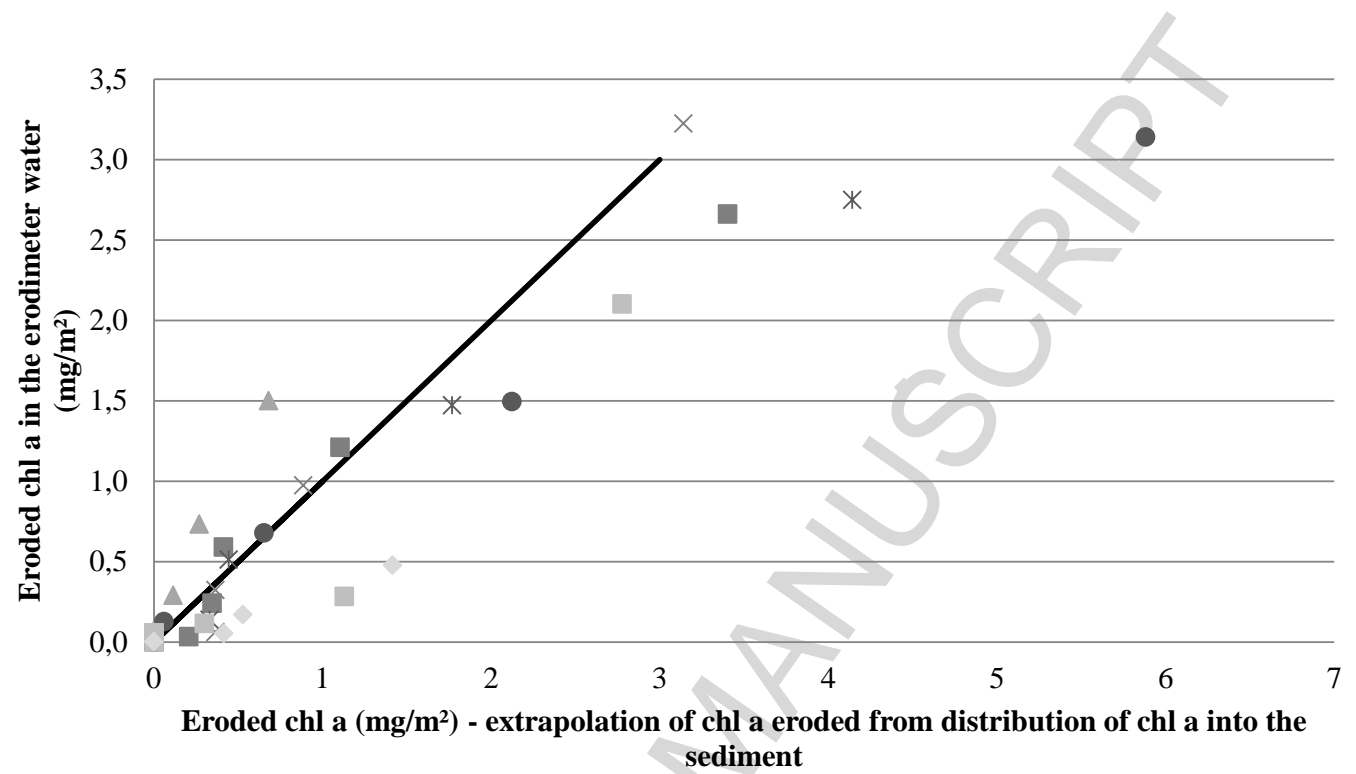

- 17

- 18

$\times 19$

* 21

- 22

- 23

- 24

—line 1:1 sediment

B

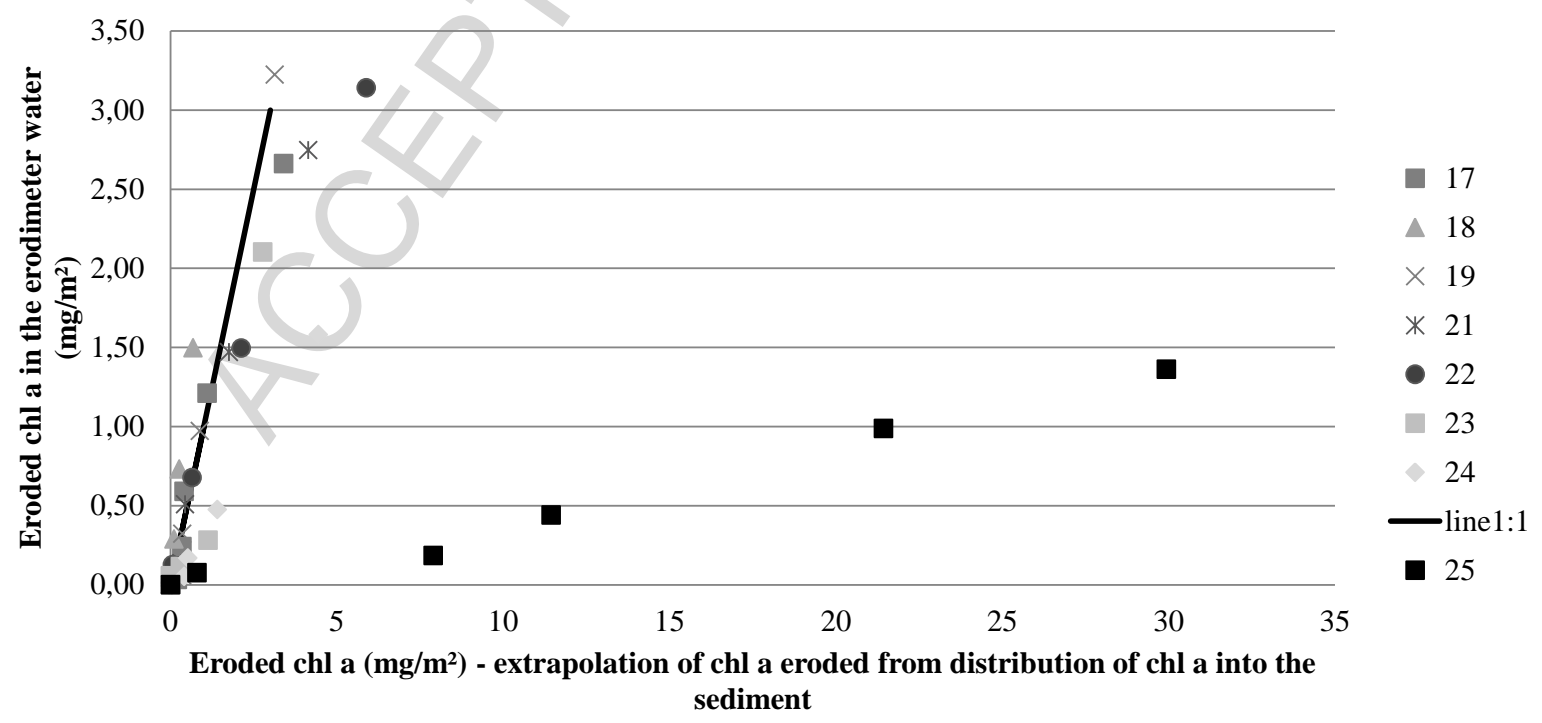

Figure 4 : 


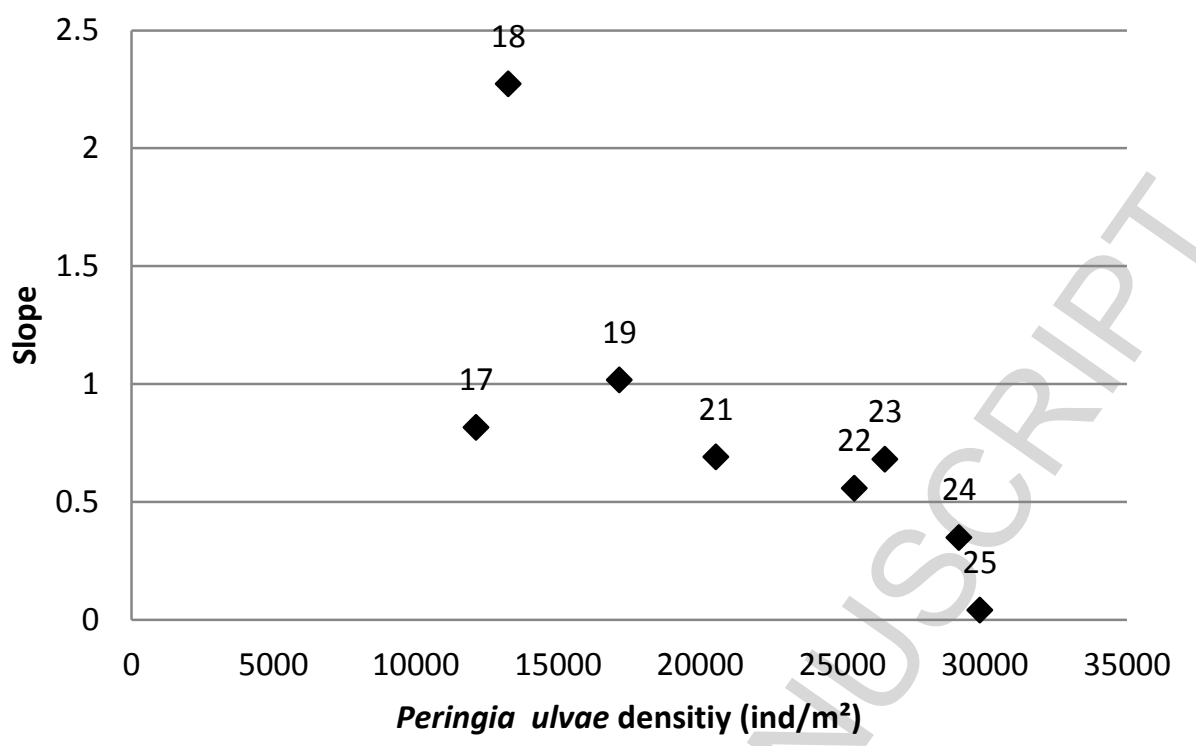

Figure 5: 
Table 1 : Taxonomic composition of diatoms: mean percentage for different erodimetre experiments

\begin{tabular}{|c|c|c|c|c|c|c|c|c|c|c|c|c|c|c|c|c|c|c|}
\hline \multirow[b]{2}{*}{$\begin{array}{l}\text { Date of } \\
\text { experiment }\end{array}$} & \multicolumn{12}{|c|}{ Diatoms $<60 \mu \mathrm{m}$} & \multicolumn{6}{|c|}{ Diatoms $>60 \mu \mathrm{m}$} \\
\hline & $\begin{array}{l}\text { Cylindro } \\
\text { theca } \\
\text { closteriu }\end{array}$ & $\begin{array}{c}\text { Nitzschia } \\
\text { longissima }\end{array}$ & $\begin{array}{c}\text { Tryblionella } \\
\text { punctata }\end{array}$ & $\begin{array}{l}\text { Paralia } \\
\text { sulcata }\end{array}$ & $\begin{array}{l}\text { Lithodes } \\
\text { mium } \\
\text { undulatu }\end{array}$ & $\begin{array}{c}\text { Plagiogram } \\
\text { mopsis sp. }\end{array}$ & $\begin{array}{c}\text { Navicula } \\
\text { spp. }\end{array}$ & $\begin{array}{c}\text { Gyrosigma } \\
\text { distortum }\end{array}$ & $\begin{array}{l}\text { Pleurosig } \\
\text { ma spp. }\end{array}$ & $\begin{array}{l}\text { Plagiotro } \\
\text { pis spp. }\end{array}$ & $\begin{array}{c}\text { Surirella } \\
s p .\end{array}$ & $\begin{array}{c}\text { Entomoneis } \\
\text { alata }\end{array}$ & $\begin{array}{c}\text { Gyrosigma } \\
\text { fasciola }\end{array}$ & $\begin{array}{c}\text { Gyrosigma } \\
\text { balticum }\end{array}$ & $\begin{array}{l}\text { Cylindro } \\
\text { theca sp. }\end{array}$ & $\begin{array}{c}\text { Pleurosigma } \\
\text { angulatum }\end{array}$ & $\begin{array}{c}\text { Pleurosigma } \\
\text { spp. }\end{array}$ & $\begin{array}{c}\text { Nitzschid } \\
\text { sigma }\end{array}$ \\
\hline \begin{tabular}{|l|}
$2008-07-17$ \\
\end{tabular} & 2,2 & 0 & 0 & 0 & 0,4 & 0,3 & 45,6 & 1,7 & 9,9 & 3,7 & 18,4 & 2,1 & 1,7 & 2,6 & 0,7 & 0,1 & 7,4 & 3,1 \\
\hline 2008-07-18 & 9,7 & 0 & 0 & 0 & 1 & 0,7 & 48,9 & 3,2 & 9,6 & 8,5 & 8,3 & 2,9 & 0,3 & 0 & 1,8 & 0 & 2,2 & 3 \\
\hline 2008-07-19 & 0,9 & 0 & 2,6 & 0 & 1,1 & 2,2 & 23,3 & 0 & 5,8 & 0,6 & 46 & 0,8 & 0 & 0,3 & 0 & 1,6 & 14,5 & 0,4 \\
\hline $2008-07-21$ & 0,6 & 0 & 0 & 0 & 4,3 & 3,2 & 18,8 & 0 & 5,1 & 4,8 & 56,7 & 0,8 & 0 & 0,1 & 0 & 1,6 & 4 & 0 \\
\hline $2008-07-22$ & 9,5 & 0 & 0 & 2,9 & 2,2 & 1,2 & 22,7 & 0 & 3,3 & 1,9 & 35 & 0,7 & 0 & 1,5 & 0 & 8,1 & 11,1 & 0 \\
\hline 2008-07-23 & 2,3 & 1 & 0 & 0 & 0 & 0 & 48,2 & 0 & 3,1 & 0,3 & 34 & 3,5 & 0 & 0 & 0 & 0,2 & 7,2 & 0 \\
\hline $2008-07-24$ & 1 & 0 & 0 & 0 & 0 & 0,7 & 51,7 & 0 & 2,5 & 0,2 & 15,3 & 8,6 & 0,3 & 0 & 2,8 & 4,5 & 8,7 & 3,6 \\
\hline $2008-07-25$ & 0,2 & 0 & 0 & 0,6 & 0 & 7,1 & 60,8 & 0 & 5,8 & 0 & 8,3 & 1,6 & 2,3 & 0 & 3,9 & 1,5 & 6 & 2 \\
\hline
\end{tabular}

